\title{
Alterations in the Baroreceptor-Heart Rate Reflex in Conscious Inbred Polydipsic (STR/N) Mice
}

\author{
C. P. CHU ${ }^{1^{*}}$, B. R. CUI ${ }^{1,2^{*}}$, H. KANNAN ${ }^{3}$, D. L. QIU ${ }^{1,4}$ \\ * These authors contributed equally to this work.
}

${ }^{1}$ Cellular Function Research Center, Yanbian University, Yanji City, China, ${ }^{2}$ Department of Osteology, Affiliated Hospital of Yanbian University, Yanji City, China, ${ }^{3}$ Department of Nutrition, Faculty of Home Economics, Kyushu Women's University, Kitakyushu, Japan, ${ }^{4}$ Department of Physiology and Pathophysiology, College of Medicine, Yanbian University, Yanji City, China

Received April 29, 2014

Accepted August 22, 2014

On-line October 15, 2014

\section{Summary}

$\mathrm{STR} / \mathrm{N}$ is an inbred strain of mice which is known to exhibit extreme polydipsia and polyuria. We previously found central administration of angiotensin II enhanced cardiovascular responses in STR/N mice than normal mice, suggesting that $\mathrm{STR} / \mathrm{N}$ mice might exhibit different cardiovascular responses. Therefore, in this study, we investigated daily mean arterial blood pressure and heart rate, and changes in the baroreceptor-heart rate reflex in conscious STR/N mice and control (ICR) mice. We found that variability in daily mean arterial blood pressure and heart rate was significantly larger in STR/N mice than in ICR mice $(p<0.05)$. There was a stronger response to phenylephrine $(P E)$ in STR/N mice than in ICR mice. For baroreceptor reflex sensitivity, in the rapid response period, the slopes of PE and sodium nitroprusside (SNP) were more negative in STR/N mice than in ICR mice. In the later period, the slopes of PE and SNP were negatively correlated between heart rate and blood pressure in ICR mice, but their slopes were positively correlated in STR/N mice. These results indicated that STR/N mice exhibited the different cardiovascular responses than ICR mice, suggesting that the dysfunction of baroreceptor reflex happened in conscious STR/N mice.

\section{Key words}

Phenylephrine - Sodium nitroprusside • Baroreceptor reflex • Inbred polydipsic mice

\section{Corresponding author}

D. L. Qiu, Cellular Function Research Center, Yanbian University,
977 GongYuan Road, Yanji City, Jilin Province, 133002, China. Fax: +86-433-2435051. E-mail: dlqiu@ybu.edu.cn or dlqiu_neuron@hotmail.com

\section{Introduction}

The inbred polydipsic mice $(\mathrm{STR} / \mathrm{N})$ that was originally developed for studies of gastric neoplasia, was transferred to the Inbred Colony of the National Institutes of Health in 1951 (Carter et al. 1952), a genetic abnormality characterized by an extreme polydipsia and polyuria. Unlike polydipsic Brattleboro rats (Schmale and Richter 1984), STR/N strain mice do not possess mutations in the arginine vasopressin (AVP) and the AVP receptor genes. The AVP mRNA in the hypothalamic paraventricular nucleus (PVN) and supraoptic nuclei (SON) were increased in STR/N mice than in control mice (Ison et al. 1993, Yambe et al. 2000).

The angiotensin II (ANG II) stimulates thirst and drinking behavior. In STR/N mice, however, the responses of neurons of the anteroventral third ventricle region to angiotensin II (ANG II) are significantly attenuated (Hattori and Koizumi 1990) and ANG II receptor binding is abundant in the brain stem region, particularly in the nucleus tractus solitarius (NTS) (Tribollet et al. 2002). Substantial evidence has been accumulated suggesting that circulating vasoactive peptides, such as ANG II and AVP, act at the central nervous system to modulate sympathetic and vagal 
activity, and ultimately regulate baroreflex sensitivity (BRS) (Bishop and Hay 1993, Hasser et al. 1997, Bishop and Sanderford 2000).

The arterial baroreflex is an important determinant of neural regulation of the cardiovascular system. Baroreflex-mediated sympathoexcitation contributes to the development and progression of many cardiovascular disorders. Accordingly, the quantitative estimation of the arterial baroreceptor-heart rate reflex has been regarded as a synthetic index of neural regulation at the sinus atrial node. Evaluation of BRS provides clinical and prognostic information in a variety of cardiovascular diseases (La Rovere et al. 2013). In normal physiological conditions, changes in arterial pressure affect sympathetic nerve activity via the neural arc, and changes in sympathetic nerve activity, in turn, affect arterial pressure via the peripheral arc. The vasoactive peptides ANG II and AVP are thought to be involved in the modulation of baroreflex control of heart rate by central sites, such as the area postrema and the nucleus tractus solitarius (NTS) (Cox and Bishop 1991, Matsukawa and Reid 1990, Peuler et al. 1990). On the other hand, some reports indicate that a chronic hypotension might cause polydipsia because of an inhibitory influence of arterial baroreceptors on water intake (Rettig and Johnson 1986, Robinson and Evered 1987). We found arterial blood pressure of the polydipsic mice was lower than control mice (Chu et al. 2003), and enhanced effects of central exogenous ANG II on cardiovascular and drinking responses in inbred polydipsic $(\mathrm{STR} / \mathrm{N})$ mice. Thus the polydipsia is likely to be related to baroreceptor activity in STR/N mice. This remains to be determined.

Taken together, these findings suggest that BRS may be changed in STR/N mice. However, this remains to be determined. Therefore, the objective of the current study was to investigate changes in BRS of STR/N mice by examining cardiovascular parameters and responses of vasoactive drugs.

\section{Materials and Methods}

\section{Animals}

Male inbred polydipsic STR/N strain mice and ICR (Institute of Cancer Research, also known as SwissWebster, controls) mice at 16-18 weeks of age were used. All experiments were approved by the Committee on Animal Care of Miyazaki Medical College. STR/N and ICR mice were kept in the Miyazaki Medical College
Experimental Animal Center under controlled conditions, at a temperature of $23 \pm 2{ }^{\circ} \mathrm{C}$ and humidity of $60 \pm 10 \%$. Animals were fed standard mouse chow and had access to tap water ad libitum.

\section{Animal preparation and data collection}

Mice were anesthetized with pentobarbital sodium (50 mg/kg, i.p.). Supplemental doses of anesthetics (1/5 of the initial dose) were administered as required to prevent eye blinking and withdrawal reflexes (Chu et al. 2003). The femoral artery and vein were exposed, and PE-10 tubing heat-coupled to PE-50 tubing of two catheters were filled with heparinized $(100 \mathrm{U} / \mathrm{ml})$ saline. These were inserted into the femoral artery and vein for arterial BP measurement and drug injections, respectively. The catheters were then tunneled subcutaneously, exteriorized, and placed at the back of the neck. The arterial catheter was connected to a BP transducer (Gould, Saddle Brook, NJ, USA) placed in a horizontal position level with the heart to monitor arterial BP. Heart rate (HR) was measured using a cardiotachometer (AT601G, Nihon Kohden, Tokyo, Japan) triggered by the rising portion of arterial BP. Signals were sent to data acquisition systems (Intelligent Instrumentation, Inc., Tucson, AZ, USA) for the calculation of mean arterial blood pressure (MABP) and HR. Mice were put into a custom-made special cage for recovery and experimental recording.

\section{Twenty-four-hour BP recording}

All experiments were performed on conscious, freely moving mice, 3 days after surgery. The STR/N and ICR mice were maintained on a 12-h light/dark cycle, and received food and water ad libitum. BP and HR were recorded continuously for $24 \mathrm{~h}$ using computer systems for 1 day, starting in the morning at 06:00 to the next morning at 06:00.

\section{Evaluation of baroreflex control of $H R$}

All experiments were performed on conscious, freely moving mice, 3 days after surgery. Baroreflex control of HR was determined by recording reflex changes in $\mathrm{HR}$ in response to transient increases in MABP produced by bolus injections of graded doses of phenylephrine (PE, stocking solution is $2.5 \mu \mathrm{g} / 25 \mu \mathrm{l}$, $10 \mu \mathrm{g} / \mathrm{kg}, 25 \mu \mathrm{g} / \mathrm{kg}$ and $35 \mu \mathrm{g} / \mathrm{kg}$, Sigma), or decreases in MABP induced by sodium nitroprusside (SNP, stocking solution is $2.5 \mu \mathrm{g} / 25 \mu \mathrm{l}, 5 \mu \mathrm{g} / \mathrm{kg}, 15 \mu \mathrm{g} / \mathrm{kg}$ and $25 \mu \mathrm{g} / \mathrm{kg}$, Sigma) into the femoral vein. At the end of injections (up 
to $15 \mu \mathrm{l} / \mathrm{mouse}$ ), catheters were immediately flushed with $35 \mu \mathrm{l}$ saline at $250 \mu \mathrm{l} / \mathrm{min}$ (by a pump, kdScientific, USA). BP and HR returned to basal levels before the next dose was given. To investigate changes in the correlation of BP and HR in full time, the data were divided into two time periods according to the mean values of the time courses of every dose. The rapid response period was determined from the baseline to the peak (SNP) or nadir (PE) of the HR response to SNP or PE (rectangular box shown in Figs 1, 2). The later period was defined as the time after the rapid response period to HR recovery. The best fit linear relationship between reflex changes in HR and changes in MABP was plotted and the slope was calculated.

\section{Statistical analysis}

All data are expressed as means $\pm \mathrm{SE}$. Statistical analyses were performed using ANOVA. Maximum changes from control values were analyzed using the Student's t-test. To analyze baroreflex responses, HR values during $\mathrm{PE}$ or SNP were plotted against the corresponding MABP values for each mouse, and the data were subjected to linear regression analysis. A value of $p<0.05$ was considered statistically significant.
A

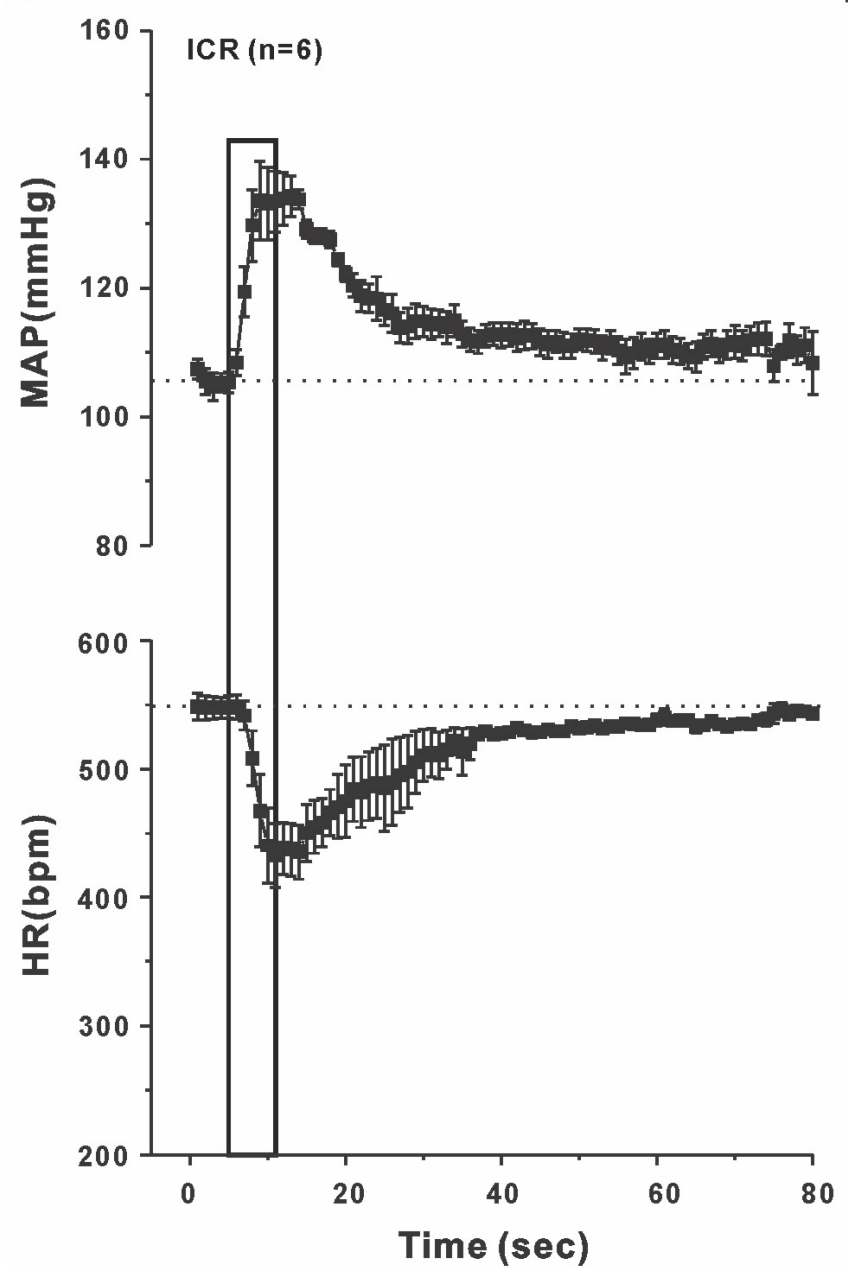

B

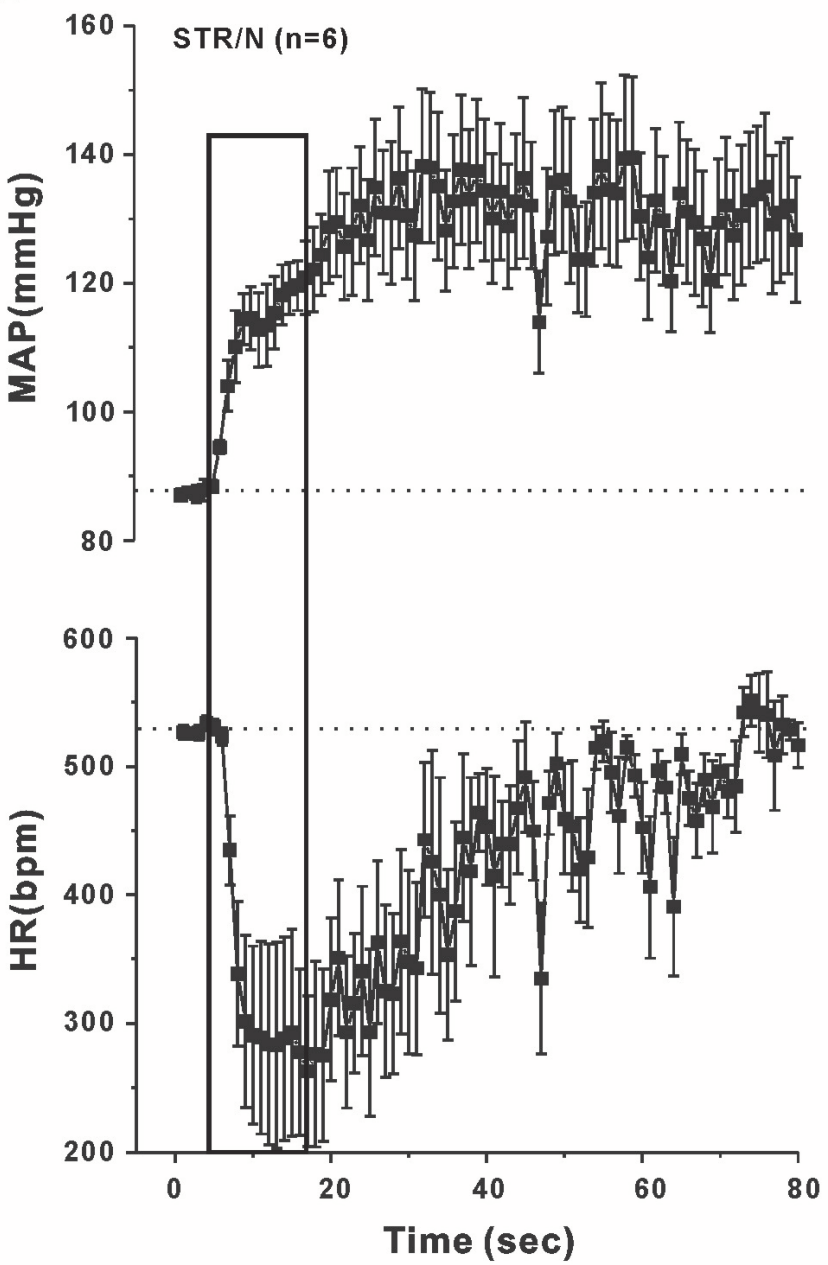

Fig. 1. Time course of changes in mean arterial blood pressure (MABP) and heart rate (HR) after i.v. administration of $P E(25 \mu \mathrm{g} / \mathrm{kg})$ in conscious mice. A: ICR mice; B: STR/N mice. The rectangular box indicates the rapid response period; bpm, beats/min; $n$, number of animals. All data are means \pm SE.

\section{Results}

\section{Basal BP and HR}

MABP and HR were measured 3 days after the surgery in STR/N and ICR mice in a conscious, freely moving state (Table 1). Twenty-four-hour MABP was 87.2 $\pm 3.5 \mathrm{~mm} \mathrm{Hg}$ in $\mathrm{STR} / \mathrm{N}$ mice and $108.7 \pm 2.5 \mathrm{~mm} \mathrm{Hg}$ in ICR mice. MABP of STR/N mice was significantly lower than that of ICR mice $(p<0.01)$, but mean HR was similar in both strains of mice $(537.5 \pm 11.1$ and 
$553.0 \pm 26.4$ beats $/ \mathrm{min}$ in STR/N and ICR mice, respectively). During $24 \mathrm{~h}$, the peak and nadir of BP were significantly lower in STR/N mice than in ICR mice $(p<0.05)$. However, the peak daily HR was significantly higher in STR/N mice than in ICR mice $(p<0.05)$ and the

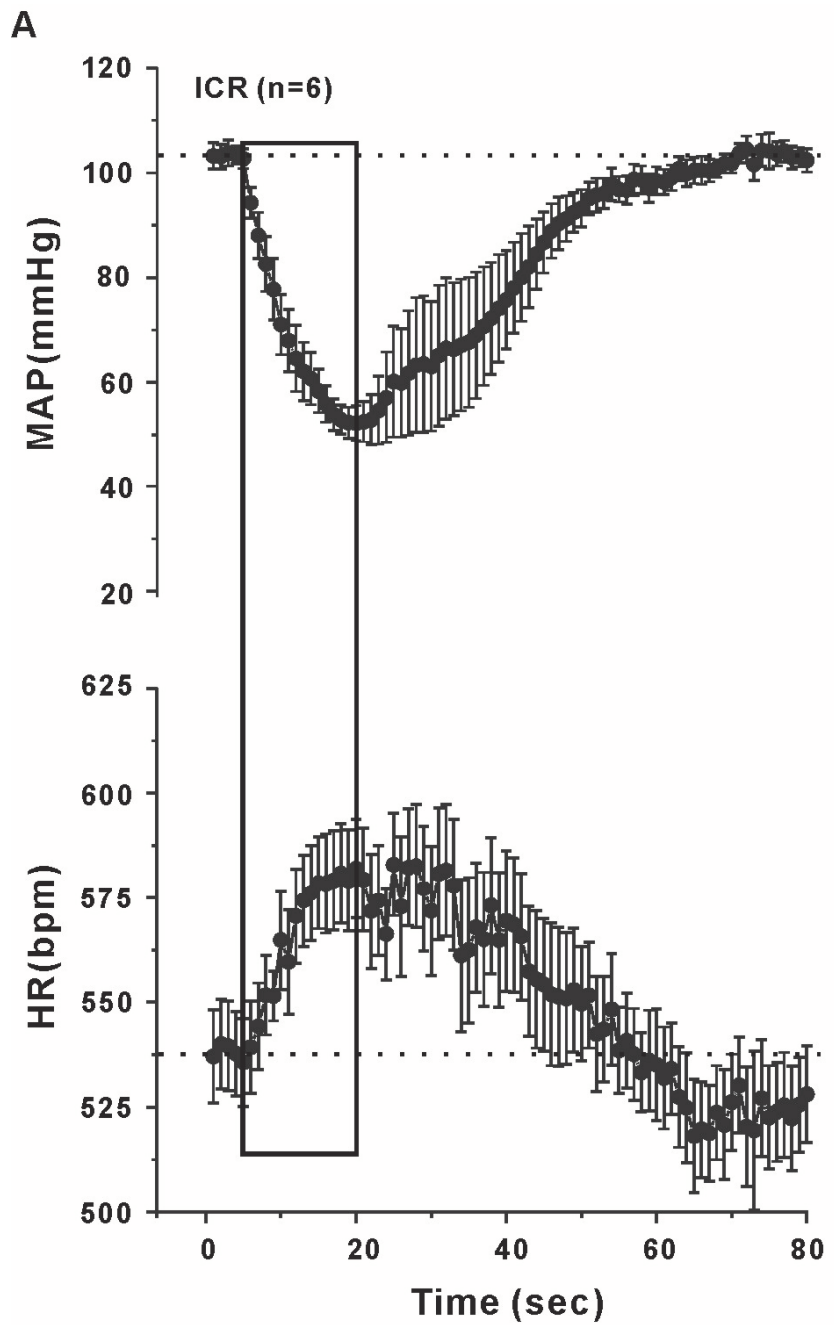

nadir of daily HR was significantly lower in STR/N mice than in ICR mice $(\mathrm{p}<0.05)$. The absolute changes in MABP $(p<0.05)$ and HR $(p<0.05)$ over $24 \mathrm{~h}$ in STR/N mice were significantly higher than those in ICR mice.

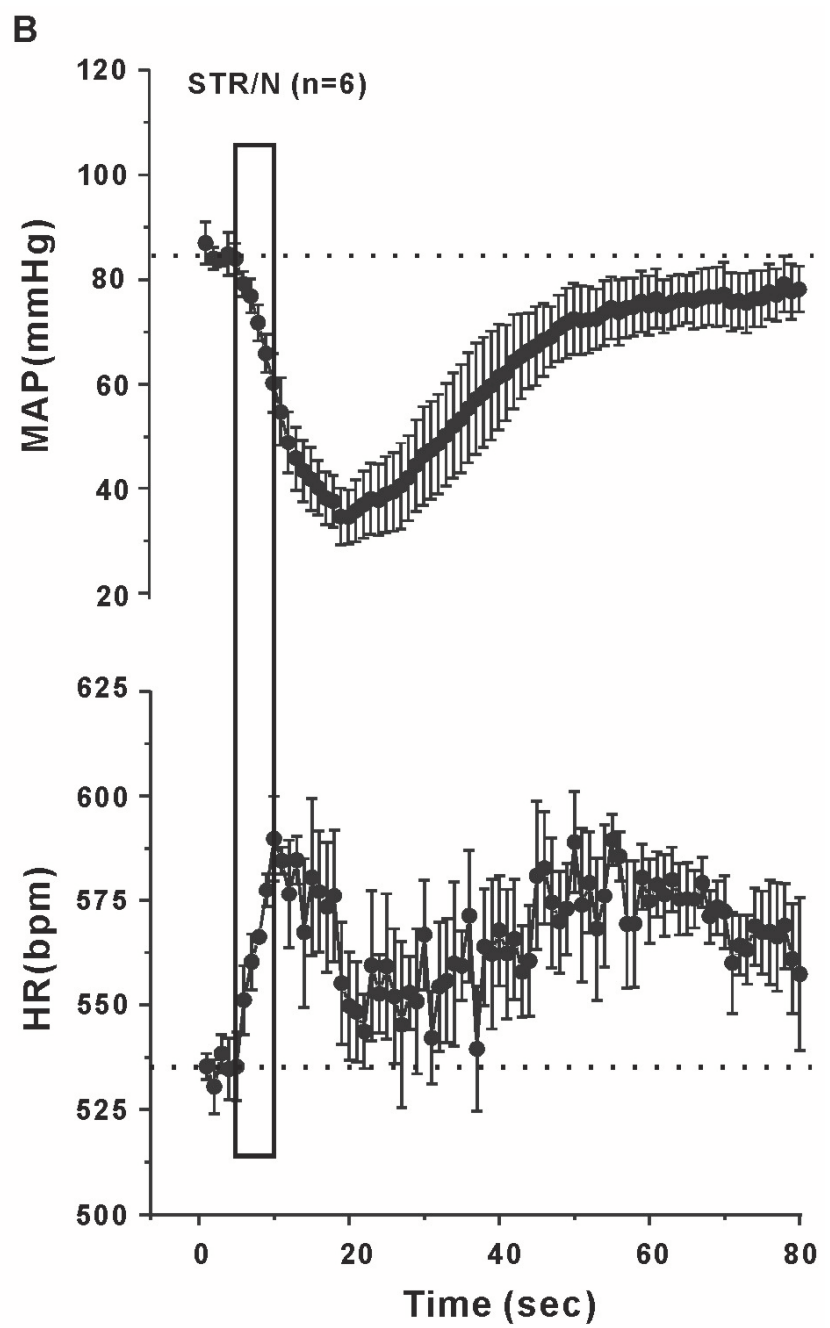

Fig. 2. Time course of changes in mean arterial blood pressure (MABP) and heart rate (HR) after i.v. administration of SNP ( $25 \mu \mathrm{gg} / \mathrm{kg})$ in conscious mice. A: ICR mice; B: STR/N mice. The rectangular box indicates the rapid response period; bpm, beats/min; $n$, number of animals. All data are means \pm SE.

Table 1. Daily basal parameters of MABP and HR in conscious ICR and SRT/N mice.

\begin{tabular}{lcccccc}
\hline & Animal & $\mathbf{n}$ & Mean & Tiptop & Nadir & Change \\
\hline \multirow{3}{*}{$M A B P(\mathrm{~mm} \mathrm{Hg})$} & $\mathrm{ICR}$ & 9 & $108.7 \pm 2.5$ & $113.6 \pm 2.4$ & $100.4 \pm 1.8$ & $13.2 \pm 1.6$ \\
& $\mathrm{SRT} / \mathrm{N}$ & 9 & $87.2 \pm 3.5^{* *}$ & $97.8 \pm 2.7^{*}$ & $70.4 \pm 1.7^{*}$ & $27.3 \pm 1.9^{*}$ \\
$H R(\mathrm{bpm})$ & $\mathrm{ICR}$ & 9 & $553.0 \pm 26.4$ & $597.1 \pm 28.9$ & $506.4 \pm 25.2$ & $91.3 \pm 22.3$ \\
& $\mathrm{SRT} / \mathrm{N}$ & 9 & $537.5 \pm 11.1$ & $640.5 \pm 18.7^{*}$ & $451.2 \pm 21.6^{*}$ & $189.3 \pm 27.2^{*}$ \\
\hline
\end{tabular}

Values are expressed as mean $\pm \mathrm{SE} ; \mathrm{n}$ is no. of animals. $* P<0.05$ vs. ICR. $* * P<0.01$ vs. ICR 
Table 2. Slopes of baroreflex responses to PE and SNP in ICR and STR/N mice.

\begin{tabular}{lccccccc}
\hline & \multicolumn{3}{c}{ ICR } & & \multicolumn{3}{c}{ STR/N } \\
\cline { 2 - 3 } \cline { 7 - 8 } & Slope & F values & P values & & Slope & F values & P values \\
\hline PE & & & & & & & \\
$\quad \begin{array}{l}\text { Rapid response period } \\
\text { Later period }\end{array}$ & $-3.98 \pm 0.75$ & 27.87 & $<0.005$ & & $-9.22 \pm 0.72^{*}$ & 164.55 & $<0.000005$ \\
SNP & $-3.66 \pm 0.25$ & 207.38 & $<0.000005$ & & $4.09 \pm 1.27^{* *}$ & 10.42 & $<0.005$ \\
$\quad$ Rapid response period & $-0.97 \pm 0.05$ & 435.80 & $<0.000005$ & & $-2.16 \pm 0.18^{*}$ & 144.92 & $<0.0005$ \\
$\quad$ Later period & $-1.13 \pm 0.07$ & 274.29 & $<0.000005$ & & $0.37 \pm 0.08^{* *}$ & 20.76 & $<0.00005$ \\
\hline
\end{tabular}

Values are means $\pm \mathrm{SE} ; \mathrm{n}=6$ male mice. $\mathrm{PE}$, phenylephrine; $\mathrm{SNP}$, sodium nitroprusside. $* P<0.05$ vs. ICR. \# $P<0.05$ later period vs. rapid response period

\section{Cardiovascular responses to i.v. injection of PE}

Intravenous injection of PE $(25 \mu \mathrm{g} / \mathrm{kg}$, Fig. 1) provoked an increase in MABP (STR/N: $87.8 \pm 1.7$ to $139.5 \pm 12.6 \mathrm{~mm} \mathrm{Hg}$, ICR: $105.3 \pm 1.6$ to $134.2 \pm 3.1$ $\mathrm{mm} \mathrm{Hg}$ ) and a decrease in HR (STR/N: $530.9 \pm 6.0$ to $262.9 \pm 58.2$ beats $/ \mathrm{min}$, ICR: $547.7 \pm 8.5$ to $432.5 \pm 25.4$ beats/min) in both groups. MABP and HR recovered after approximately $40 \mathrm{~s}$ in ICR mice. PE caused a decrease in $\mathrm{HR}$ in STR/N mice, and this recovered after approximately $40 \mathrm{~s}$. However, the duration of BP response to $\mathrm{PE}$ in $\mathrm{STR} / \mathrm{N}$ mice $(>1200$ s) was significantly longer than that in ICR mice $(\mathrm{p}<0.05)$. The absolute increase in MABP in STR/N mice (51.3 \pm 7.7 $\mathrm{mm} \mathrm{Hg}$ ) was significantly larger than that in ICR mice (28.7 $\pm 2.4 \mathrm{~mm} \mathrm{Hg}, \mathrm{p}<0.05)$. The absolute decrease in HR in STR/N mice ( $262.8 \pm 42.4$ beats $/ \mathrm{min})$ was significantly higher than that in ICR mice $(112.7 \pm 14.9$ beats $/ \mathrm{min}$, $\mathrm{p}<0.01)$.

\section{Cardiovascular responses to i.v. injection of SNP}

Intravenous injection of SNP (25 $\mu \mathrm{g} / \mathrm{kg}$, Fig. 2) induced a decrease in MABP (STR/N: $84.1 \pm 2.1$ to $34.6 \pm 5.1 \mathrm{~mm} \mathrm{Hg}$, ICR: $103.8 \pm 2.5$ to $52.2 \pm 3.4 \mathrm{~mm} \mathrm{Hg}$ ) and an increase in HR (STR/N: $535.3 \pm 8.2$ to $589.8 \pm 10.1$ beats $/ \mathrm{min}$, ICR: $535.7 \pm 10.5$ to $583.3 \pm 14.8$ beats $/ \mathrm{min}$ ). The decrease in MABP caused by SNP in STR/N mice recovered after $50 \mathrm{~s}$. However, the duration of the HR response to SNP in STR/N mice was unstable within approximately $80 \mathrm{~s}$. The absolute decrease in MABP $(49.3 \pm 2.7 \mathrm{~mm} \mathrm{Hg})$ in STR/N mice was similar to that in ICR mice $(50.8 \pm 3.0 \mathrm{~mm} \mathrm{Hg}, \mathrm{p}>0.05)$. The absolute increase in HR $(51.5 \pm 8.0$ beats $/ \mathrm{min})$ in STR/N mice was similar to that in ICR mice ( $46.4 \pm 9.1$ beats/min, $\mathrm{p}>0.05)$.

\section{Baroreflex response to PE and SNP}

In the rapid response period, ANOVA of the linear regression showed a significant dependence of $\mathrm{HR}$ on $\mathrm{BP}$ in ICR and STR/N mice. There was also a negative correlation between HR and BP in response to PE or SNP in both strains of mice (Table 2 and Fig. 3). For statistical analysis in which data from all observations were pooled, slopes for the response to PE or SNP were significantly more negative for STR $/ \mathrm{N}$ mice (slope $=-9.22 \pm 0.72$ with PE; $-2.16 \pm 0.18$ with SNP) than for ICR mice (slope $=$ $-3.98 \pm 0.75$ with PE; $-0.97 \pm 0.05$ with $\mathrm{SNP})(\mathrm{p}<0.05$, Table 2). In the later period, ANOVA of linear regression showed a significant dependence of $\mathrm{HR}$ on $\mathrm{BP}$ in response to PE or SNP for ICR and STR/N mice. There was a negative correlation between $\mathrm{HR}$ and $\mathrm{BP}$ in response to PE or SNP, and no significant difference between the rapid response and later period in ICR mice (Table 2). However, there was a negative correlation between HR and BP in the rapid response period and a positive correlation in the later period in response to $\mathrm{PE}$ or SNP in STR $/ \mathrm{N}$ mice (slope $=4.09 \pm 1.27$ with PE; $0.37 \pm 0.08$ with SNP). There was a significant difference between the rapid response and later periods in STR/N mice $(\mathrm{p}<0.05)$ (Table 2 and Fig. 3 ).

\section{Discussion}

The present study found that in conscious mice 1) the absolute change in MABP and HR values over $24 \mathrm{~h}$ was significantly larger in STR/N mice than in ICR mice, 2) there was a stronger response to $P E$ in $S T R / N$ mice than in ICR mice, and 3) with regard to BRS, in the rapid response period, the slopes of PE and SNP were more negative in STR/N mice than in ICR mice. In the later period, the slopes of PE and SNP changed to a 
positive correlation between $\mathrm{HR}$ and $\mathrm{BP}$ in STR/N mice.

These data demonstrate that baroreflex activity is altered
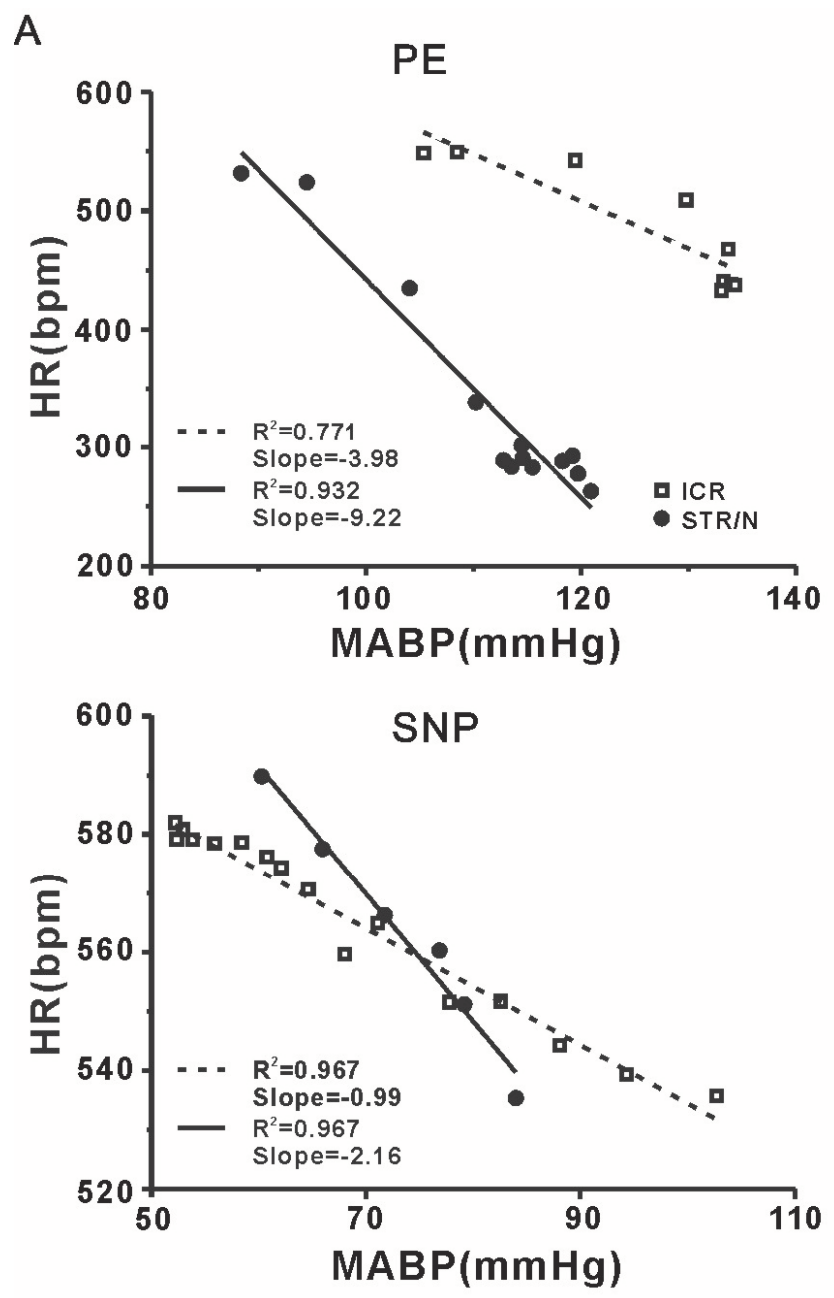

in STR/N mice, particularly in the later period, where the negative correlation between BP and HR disappears.
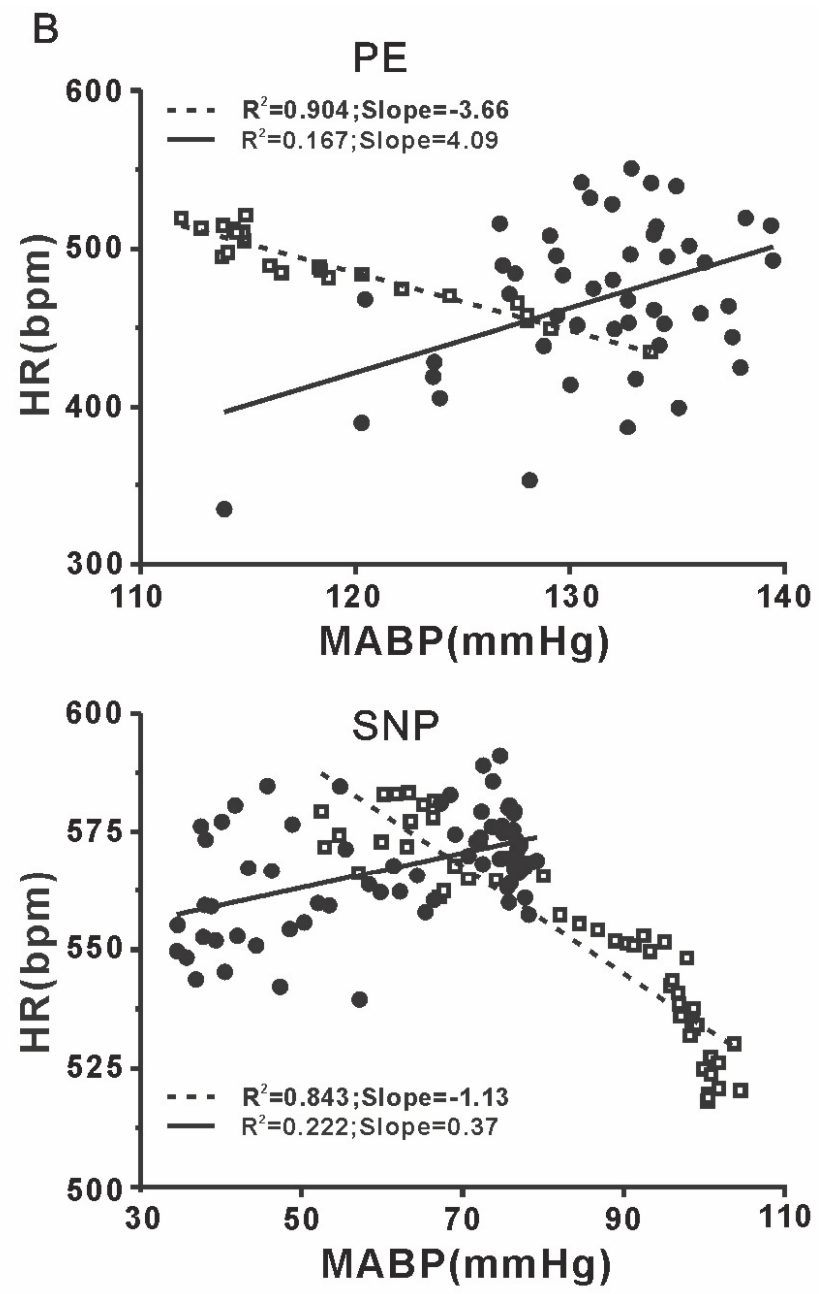

Fig. 3. Baroreflex sensitivity. A: Regression lines for the association between HR and MABP at the rapid response period (rectangular box shown in Figs 1, 2) for PE (top) and SNP (bottom) in STR/N and ICR mice. B: Regression lines for the association between HR and MABP at the later period (period of time after the response period) for PE (top) and SNP (bottom) in STR/N and ICR mice. Dashed lines are the average slopes of the regression lines in ICR mice. Thick lines are the average slopes of the regression lines in STR/N mice. $n=6$

The present study showed that the absolute change in daily MABP and HR in STR/N mice was significantly higher than that in ICR mice (Table 1). The arterial baroreceptor reflex system plays a predominant role in preventing short-term wide fluctuations of arterial BP in many animal species. Arterial baroreceptor denervation results in an increase in variability of BP (Cowley et al. 1973). Basic pathways mediating reflex control of HR involve baroreceptors, afferents to the central nervous system, the cardiovascular center in the central nervous system, and sympathetic and parasympathetic efferents to the heart (Kumada et al. 1990). Impairment at any point along these pathways leads to an altered baroreflex. While the mechanisms for this process are still unclear, the renin-angiotensin system and other humoral and/or hormonal factors may be involved (Lohmeier 2001, Nishida et al. 2012). STR/N mice have different central ANG II and AVP systems compared with controls (Nishi et al. 1999, Hattori and Koizumi 1990, Tribollet et al. 2002, Chu et al. 2003). The instability of BP and HR implies impairment of the baroreflex in STR/N mice. In addition, prolonged stimulation of the baroreceptors can produce decreases in BP that last for up to 1 week (Lohmeier et al. 2005). Such data support the hypothesis that the baroreflex is not only important in moment-to-moment regulation, but is also involved in long-term regulation, and therefore may influence more chronic maladaptations. A low BP in 
$\mathrm{STR} / \mathrm{N}$ mice has been previously reported by our group (Chu et al. 2003). One possible explanation for the lower basal BP in STR/N mice compared with controls in the present study is the occurrence of an increased gain of the baroreflex. Our results indicated that in the rapid response period, the slopes of PE and SNP were more negative in $\mathrm{STR} / \mathrm{N}$ mice than in ICR mice (Fig. 3 and Table 2). Holschneider et al. (2002) reported that the baroreceptor response was increased in MAO-A/B KO mice with evident lower BP. Under normotensive conditions, baroreceptor input tonically inhibits sympathetic effects on blood vessels and the heart. An increased gain of the baroreflex could lead to lower BP in response to the excessive basal levels of pressor amines. Results of the present study are consistent with this possibility. However, we cannot exclude the possibility that an altered set point may induce lower basal BP, which can occur through serotonergic mechanisms thought to be independent of the baroreceptor reflex (Nosjean et al. 1995, Tsukamoto et al. 2000). Yambe et al. (2000) reported that dehydration occurred with the acceleration of AVP synthesis because of deterioration of AVP sensitivity in 20 -week-old STR/N mice. Therefore, it is conceivable that relative hypovolemia secondary to increased urine output in STR/N mice might result in decreased BP.

This study indicated that there was a stronger response to PE in STR/N mice than in ICR mice (Fig. 1). $\mathrm{PE}$ is an $\alpha 1$-adrenergic agonist. Masuki et al. (2003, 2005) reported that enhanced baroreflex control of HR might compensate for blunted peripheral $\alpha$-adrenergic responsiveness in blood vessels, helping to maintain the stability of arterial BP. Our results showed that baroreflex control of HR and peripheral $\alpha$-adrenergic responsiveness in blood vessels were enhanced in STR/N mice compared with ICR mice (Figs 1,3A). Although the abnormity of the $\alpha$-adrenergic system has not been reported, as mentioned above, STR/N mice have a different central ANG II system compared with controls (Hattori and Koizumi 1990, Tribollet et al. 2002, Chu et al. 2003). Cross-talk between angiotensin type 1 receptor and $\alpha 1$ adrenergic receptors has been reported and indicates the existence of physiological regulation between the reninangiotensin system and the sympathetic nervous system at the receptor level in the brain (Crespo 2000, Stadler et al. 1992). There is endothelium-dependent cross-talk between $\alpha 1$-adrenergic and ANG II receptors in smooth muscle of the rabbit aorta (Jerez et al. 2004). These results suggest that the adrenergic system might be changed in STR/N mice. Future studies will be required to determine this issue.

Recently, some reports have suggested that BRS is reduced during hypertension and increased during hypotension (Braga 2010, Botelho-Ono et al. 2011, Guimarães et al. 2012, Queiroz et al. 2012, Holschneider et al. 2002). This finding is consistent with our results. Previously, we reported a lower BP in STR/N mice (Chu et al. 2003). The present study showed that in the baroreflex response to PE and SNP, the slopes were more negative in STR/N mice than in ICR mice in the rapid response period (Table 2). This indicated an increased gain of the baroreflex in STR/N mice. Nishi et al. (1999) reported that AVP mRNA levels in the hypothalamus were higher in polydipsic STR/N mice than in control ICR mice. Transgenic animal research has shown that $\mathrm{V} 1 \mathrm{a}^{-/-}$mice (Koshimizu et al. 2006) and AVP-deficient mutant Brattleboro rats have attenuated BRS (Imai et al. 1983a,b). AVP has been shown to enhance baroreflex function via activation of $\mathrm{V} 1$ receptors in the area postrema (Hasser and Bishop 1990, Scheuer and Bishop 1996, Cox and Bishop 1991). Circulating AVP increases the gain or sensitivity of the baroreflex through its action in the area postrema (Cowley and Barber 1983, Hasser et al. 1997). This might be a reason for enhanced BRS in $\mathrm{STR} / \mathrm{N}$ mice. The mechanisms of the alteration of baroreflex activity in STR/N mice need to be studied in the future.

A key component of baroreceptor reflex is the baroreceptor-HR reflex which induces rapid $\mathrm{HR}$ responses to alterations in BP. Under normal condition, activation of arterial baroreceptors by a rise in systemic arterial pressure leads to an increase of the discharge of vagal cardioinhibitory neurons and decrease in the discharge of sympathetic neurons both to decrease HR. Conversely, a decrease in systemic arterial pressure causes the deactivation of baroreceptors with subsequent enhancement of sympathetic activity and vagal inhibition, leading to tachycardia (La Rovere et al. 2008). In the present study, we found that BP and HR gradually returned to normal follow the baroreceptor reflex principle at the end of the potency of PE and SNP in ICR mice. However, the correlations between MABP and HR were reversed in the later period of the baroreceptor reflex in STR/N mice. This kind of alteration might be due to changes in AVP, ANG II, or adrenergic systems in $\mathrm{STR} / \mathrm{N}$ mice. It is remained unclear.

In conclusion, the present study indicated that STR/N mice exhibited the different cardiovascular 
responses than ICR mice, suggesting that the dysfunction of baroreceptor reflex happened in conscious STR/N mice.

\section{Conflict of Interest}

There is no conflict of interest.

\section{Acknowledgements}

This work was supported in part by grants-in-aid for scientific research (10557009 and 11470019) from the Ministry of Education, Science, Sports, and Culture, Japan. This work was also partially supported by the National Natural Science Foundation of China (81260208, 31060138, and 31260245).

\section{References}

BISHOP VS, HAY M: Involvement of the area postrema in the regulation of sympathetic outflow to the cardiovascular system. Front Neuroendocrinol 14: 57-75, 1993.

BISHOP VS, SANDERFORD MG: Angiotensin II modulation of the arterial baroreflex: role of the area postrema. Clin Exp Pharmacol Physiol 27: 428-431, 2000.

BOTELHO-ONO MS, PINA HV, SOUSA KHF, NUNES FC, MEDEIROS IA, BRAGA VA: Acute superoxide scavenging restores depressed baroreflex sensitivity in renovascular hypertensive rats. Auton Neurosci 159: 3844, 2011.

BRAGA VA: Dietary salt enhances angiotensin-II-induced superoxide formation in the rostral ventrolateral medulla. Auton Neurosci 155: 14-18, 2010.

CARTER TC, DUNN LC, FALCONER DS, GRUNEBERG H, HESTON WE, SNELL GD: Standardized nomenclature for inbred strains of mice. Cancer Res 12: 602-613, 1952.

CHU CP, KATO K, KUNITAKE T, WATANABE S, QIU DL, UETA Y, KANNAN H: Enhanced effects of central angiotensin II on cardiovascular and drinking responses in inbred polydipsic (STR/N) mice. Brain Res 962: 129-134, 2003.

COWLEY AW Jr, BARBER BJ: Vasopressin vascular and reflex effects - a theoretical analysis. Prog Brain Res 60: 415-424, 1983.

COWLEY AW Jr, LIARD JF, GUYTON AC: Role of baroreceptor reflex in daily control of arterial blood pressure and other variables in dogs. Circ Res 32: 564-576, 1973.

COX BF, BISHOP VS: Neural and humoral mechanisms of angiotensin-dependent hypertension. Am J Physiol 261: H1284-H1291, 1991.

CRESPO MJ: Interaction between AT1 and alpha1-adrenergic receptors in cardiomyopathic hamsters. $J$ Card Fail 6: 257-263, 2000.

FINK GD, BRUNER CA, MANGIAPANE ML: Area postrema is critical for angiotensin-induced hypertension in rats. Hypertension 9: 355-361, 1987.

GUIMARÃES DD, CARVALHO CC, BRAGA VA: Scavenging of NADPH oxidase-derived superoxide anions improves depressed baroreflex sensitivity in spontaneously hypertensive rats. Clin Exp Pharmacol Physiol 39: 373-378, 2012.

HASSER EM, BISHOP VS: Reflex effect of vasopressin after blockade of V1 receptors in the area postrema. Circ Res 67: 265-271, 1990.

HASSER EM, BISHOP VS, HAY M: Interactions between vasopressin and baroreflex control of the sympathetic nervous system. Clin Exp Pharmacol Physiol 24: 102-108, 1997.

HATTORI Y, KOIZUMI K: Sensitivity to angiotensin II of neurons in the circumventricular organs of polydipsic inbred mice. Brain Res 524: 181-186, 1990.

HOLSCHNEIDER DP, SCREMIN OU, ROOS KP, CHIALVO DR, CHEN K, SHIH JC: Increased baroreceptor response in mice deficient in monoamine oxidase A and B. Am J Physiol 282: H964-H972, 2002.

IMAI Y, NOLAN PL, JOHNSTON CI: Endogenous vasopressin modulates the baroreflex sensitivity in rats. Clin Exp Pharmacol Physiol 10: 289-292, 1983a.

IMAI Y, NOLAN PL, JOHNSTON CI: Restoration of suppressed baroreflex sensitivity in rats with hereditary diabetes insipidus (Brattleboro rats) by arginine-vasopressin and DDAVP. Circ Res 53: 140-149, 1983 b. 
ISON A, YURI K, UETA Y, LENG G, KOIZUMI K, YAMASHITA H, KAWATA M: Vasopressin- and oxytocinimmunoreactive hypothalamic neurons of inbred polydipsic mice. Brain Res Bull 31: 405-414, 1993.

JEREZ S, PERAL DE BRUNO M, COVIELLO A: Cross talk between angiotensin II and alpha 1 adrenergic receptors in rabbit aorta: role of endothelium. J Cardiovasc Pharmacol 43: 402-409, 2004.

KOSHIMIZU TA, NASA Y, TANOUE A, OIKAWA R, KAWAHARA Y, KIYONO Y, ADACHI T, TANAKA T, KUWAKI T, MORI T, TAKEO S, OKAMURA H, TSUJIMOTO G: V1a vasopressin receptors maintain normal blood pressure by regulating circulating blood volume and baroreflex sensitivity. Proc Natl Acad Sci USA 103: 7807-7812, 2006.

KUMADA M, TERUI N, KUWAKI T: Arterial baroreceptor reflex: its central and peripheral neural mechanisms. Prog Neurobiol 35: 331-361, 1990.

LA ROVERE MT, PINNA GD, RACZAK G: Baroreflex sensitivity: measurement and clinical implications. Ann Noninvasive Electrocardiol 13: 191-207, 2008.

LA ROVERE MT, PINNA GD, MAESTRI R, SLEIGHT P: Clinical value of baroreflex sensitivity. Neth Heart $J$ 21: 61-63, 2013.

LOHMEIER TE: The sympathetic nervous system and long-term blood pressure regulation. Am J Hypertens 14: 147S$154 \mathrm{~S}, 2001$.

LOHMEIER TE, BARRETT AM, IRWIN ED: Prolonged activation of the baroreflex: a viable approach for the treatment of hypertension? Curr Hypertens Rep 7: 193-198, 2005.

MASUKI S, TAKEOKA M, TANIGUCHI S, NOSE H: Enhanced baroreflex sensitivity in free-moving calponin knockout mice. Am J Physiol 284: H939-H946, 2003.

MASUKI S, TODO T, NAKANO Y, OKAMURA H, NOSE H: Reduced alpha-adrenoceptor responsiveness and enhanced baroreflex sensitivity in Cry-deficient mice lacking a biological clock. J Physiol 566: 213-224, 2005.

MATSUKAWA S, REID IA: Role of the area postrema in the modulation of the baroreflex control of heart rate by angiotensin II. Circ Res 67: 1462-1473, 1990.

NISHI R, UETA Y, SERINO R, NOMURA M, YAMAMOTO Y, SHIBUYA I, KOIZUMI K, YAMASHITA H: Increase of vasopressin mRNA in the hypothalamus of inbred polydipsic mice. Brain Res Bull 50: 47-51, 1999.

NISHIDA Y, TANDAI-HIRUMA M, KEMURIYAMA T, HAGISAWA K: Long-term blood pressure control: is there a set-point in the brain? J Physiol Sci 62: 147-161, 2012.

NOSJEAN A, FRANC B, LAGUZZI R: Increased sympathetic nerve discharge without alteration in the sympathetic baroreflex response by serotonin3 receptor stimulation in the nucleus tractus solitarius of the rat. Neurosci Lett 186: 41-44, 1995.

PEULER JD, EDWARDS GL, SCHMID PC, JOHNSON AK: Area postrema and differential reflex effects of vasopressin and phenylephrine in rats. Am J Physiol 258: H1255-H1259, 1990.

QUEIROZ TM, GUIMARÃES DD, MENDES-JÚNIOR LG, BRAGA VA: $\alpha$-lipoic acid reduces hypertension and increases baroreflex sensitivity in renovascular hypertensive rats. Molecules 17: 13357-13367, 2012.

RETTIG R, JOHNSON AK: Aortic baroreceptor deafferentation diminishes saline-induced drinking in rats. Brain Res 370: 29-37, 1986.

ROBINSON MM, EVERED MD: Pressor action of intravenous angiotensin II reduces drinking response in rats. $A m J$ Physiol 252: R754-R759, 1987.

SCHEUER DA, BISHOP VS: Effect of vasopressin on baroreflex control of lumbar sympathetic nerve activity and hindquarter resistance. Am J Physiol 270: H1963-H1971, 1996.

SCHMALE H, RICHTER D: Single base deletion in the vasopressin gene is the cause of diabetes insipidus in Brattleboro rats. Nature 308: 705-709, 1984.

STADLER T, VELTMAR A, QADRI F, UNGER T: Angiotensin II evokes noradrenaline release from the paraventricular nucleus in conscious rats. Brain Res 569: 117-122, 1992.

TRIBOLLET E, UETA Y, HEITZ F, MARGUERAT A, KOIZUMI K, YAMASHITA H: Up-regulation of vasopressin and angiotensin II receptors in the thalamus and brainstem of inbred polydipsic mice. Neuroendocrinology 75 : $113-123,2002$. 
TSUKAMOTO K, KURIHARA T, NAKAYAMA N, ISOGAI O, ITO S, KOMATSU K, KANMATSUSE K: Pressor responses to serotonin injected into the nucleus tractus solitarius of Sprague-Dawley rats and spontaneously hypertensive rats. Clin Exp Hypertens 22: 63-73, 2000.

YAMBE Y, WATANABE-TOMITA Y, KAKIYA S, YOKOI H, NAGASAKI H, ARIMA H, MURASE T, YUASA H, KONDO K, YAMASHITA H, OISO Y: Analysis of the vasopressin system and water regulation in genetically polydipsic mice. Am J Physiol 278: E189-E194, 2000. 